\title{
Towards an environmental assessment model of palaeontological and archaeological heritage in the Autonomous Valencian Community without comparative torts
}

\author{
Francisco J. RUIZ-SÁNCHEZ ${ }^{1,2 *}$, Carlos de SANTISTEBAN BOVÉ ${ }^{1}$, Rafael MARQUINA- \\ $B_{L A S O}^{1,2}$, Ana FAGOAGA $A^{1,2}$
}

\author{
${ }^{1}$ Department of Botany and Geology, Faculty of Biology, Campus de Burjassot, University of Valencia, Avenue. Dr. Moliner, \\ 46100 Valencia, Spain; francisco.ruiz@uv.es \\ ${ }^{2}$ Museu Valencià d'Història Natural, L'Hort de Feliu, P. O. Box 8460, Alginet 46018, Valencia, Spain
}

* Corresponding author

Ruiz-Sánchez, F.J., de Santisteban Bové, C., Marquina-Blaso, R. \& Fagoaga, A. 2019. Towards an environmental assessment model of palaeontological and archaeological heritage in the Autonomous Valencian Community without comparative torts. [Hacia un modelo de evaluación del patrimonio paleontológico y arqueológico en la Comunitat Valenciana sin agravios comparativos]. Spanish Journal of Palaeontology, 34 (1), 75-80.

Manuscript received 23 March 2019

Manuscript accepted 13 May 2019 https://doi 10.7203/sjp.34.1.15251

(C) Sociedad Española de Paleontología ISSN 2255-0550

\begin{abstract}
The deficient management of the paleontological heritage through the environmental impact assessment procedures from the Valencian public administrations, linked mainly to the lack of competent technical means in the matter, results in an almost abandonment of it. On the contrary, the archaeological heritage has a series of perfectly structured tools that allow any possible impact on it regarding projects and actions subject to environmental impact assessment that can be detected and corrected. The damage that this situation creates results in the abandonment and almost absolute lack of protection of the palaeontological heritage in the Valencian Community. Despite how much has been written defending the location of paleontological heritage in the administrative field of Natural Heritage, the legal reality in the whole of the Spanish state is another, being based on its inclusion in the procedures together with the cultural heritage. This work defends the incorporation of a series of small legislative changes that make possible to equate the management of the palaeontological heritage with that of the archaeological one
\end{abstract}

\section{RESUMEN}

La deficiente gestión que del patrimonio paleontológico se realiza en los procedimientos de evaluación del impacto ambiental desde las administraciones públicas valencianas, ligada sobre todo a la falta de medios técnicos competentes en la materia, redunda en un casi abandono del mismo. Por el contrario, el patrimonio arqueológico cuenta con una serie de herramientas perfectamente estructuradas que permiten que cualquier posible afección sobre él de proyectos y actuaciones sometidas a evaluación de impacto ambiental pueda ser detectada y corregida. El agravio que esta situación crea, redunda en el desconocimiento, abandono y casi absoluta desprotección del patrimonio paleontológico en la Comunitat Valenciana. A pesar de lo mucho que se ha escrito defendiendo la ubicación del patrimonio paleontológico en el ámbito administrativo del Patrimonio Natural (Ley 42/2007, del Patrimonio Natural y la Biodiversidad), la realidad legal en el conjunto del estado español es otra, y se basa en su inclusión en los procedimientos junto al patrimonio cultural propiamente dicho. En este trabajo se 
in the Valencian Community, thus avoiding the comparative torts that currently occur.

Keywords: Cultural heritage, environmental impact assessment (EIA), palaeontological heritage, Valencian Community.

\section{INTRODUCTION}

Following a tradition fully consolidated in the field of the protection of cultural heritage in the Valencian Community, there is a whole series of legal mechanisms that allow evaluating the condition that can suffer this type of values for any work, project or program. Accompanying the procedures provided in Law 2/89 of Environmental Impact and Law 4/98 of the Valencian Cultural Heritage, the Order of 3 January 2005, of the Generalitat Valenciana (Valencian Government), it is established the minimum content of environmental impact studies, specifying that these studies will identify and assess impacts, both in the proposed solution and its alternatives by incorporating, in addition to a series of other documents, the binding report in accordance with the regulations on the protection of cultural heritage set out in art.11 of Law 4/1998 of Valencian Cultural Heritage (Memoria de Impacto Patrimonial-MIP, according to Decree 208/2010) (RuizSánchez, 2018). According to the Order of 3 January 2005, the report is binding on the environmental administrative body that must carry out the environmental impact statement. Although palaeontological heritage is considered as natural heritage by Law 42/2007, the procedures related to environmental impact assessments still include the palaeontological heritage as one more element of cultural heritage. In order to clarify what should be the minimum content of MIPs (art. 11 of Law 4/1998) that could affect the assets of historical, artistic, archaeological and palaeontological heritage by plans and programs subject to strategic environmental assessment of projects subject to environmental impact study, Decree 208/2010 of the Valencian Government was promulgated.

According to Decree 208/2010, in order to evaluate the possible impact of the project, plan or programme, work or activity on the archaeological heritage, to carry out an archaeological survey will be mandatory, which shall cover the entire scope of the project under assessment, including all associated ancillary works, and shall include the prospecting of a minimum environment of 50 metres from the limit of affectation (expandable to 2000 meters in linear actions such as roads, gas pipelines, etc.) (Ruiz-Sánchez, 2018). Whereas archaeological impact assessment is field work-based, the promoter in palaeontological heritage defiende la incorporación de una serie de pequeños cambios legislativos que permitan equiparar la gestión del patrimonio paleontológico y del arqueológico en la Comunitat Valenciana, evitando de esta manera los agravios comparativos que actualmente se producen.

Palabras clave: Patrimonio cultural, evaluación del impacto ambiental (EIA), patrimonio paleontológico, Comunitat Valenciana. evaluation must consult in advance the cartographies that delimit the areas of low palaeontological potential of the Valencian Community, and if the project is entirely located in these areas, only documented justification of this circumstance should be included in the environmental impact study (Ruiz-Sánchez, 2018). The archaeologist working for the promoter uses database information from the Valencian Cultural Heritage Inventory just to contextualize the fieldwork to be developed in the impact assessment, but not cartography as in the case of palaeontological heritage.

The cartographies of "low palaeontological potential" (LPP) (Fig. 1) are a set of maps (one for each of the three provinces in which the Valencian Community is administratively divided: Castellón, Valencia and Alicante) (ABPP_GVA-Conselleria d'Educació, Investigació, Cultura i Esports, 2019) which, presumably are based on maps 1:200 000 (Gutiérrez et al., 1984; Agència del Medi Ambient, 1987; Robles et al., 1991), that identify areas from the natural environment with low palaeontological potential. In contrast, except some localities named as BIC (element of cultural interest), the cartography of palaeontological areas of relevance has not been developed by the Valencian administration. According to RuizSánchez (2018), LPP correspond almost exclusively to the Quaternary deposits (Fig. 2).

According to the latter author, the unequal treatment that the administrative procedure implemented in the Valencian Community for the assessment of the environmental impact on the Cultural Heritage of the archaeological and palaeontological heritage, causes a comparative tort which must be corrected for the effective application of the precautionary principle contained in the basic European legislation (Communication EU-[COM(2000) 1 final] on the use of the precautionary principle). According to Ruiz-Sánchez (2018), the precautionary principle set out in Article 191 of the Treaty on the Functioning of the European Union falls within the general framework of risk analysis and, more specifically, within the framework of risk management corresponding to the decision making phase (Communication EU-[COM(2000) 1 final] on the use of the precautionary principle), so it can be considered as one of the basic foundations on which the European Union is founded. 


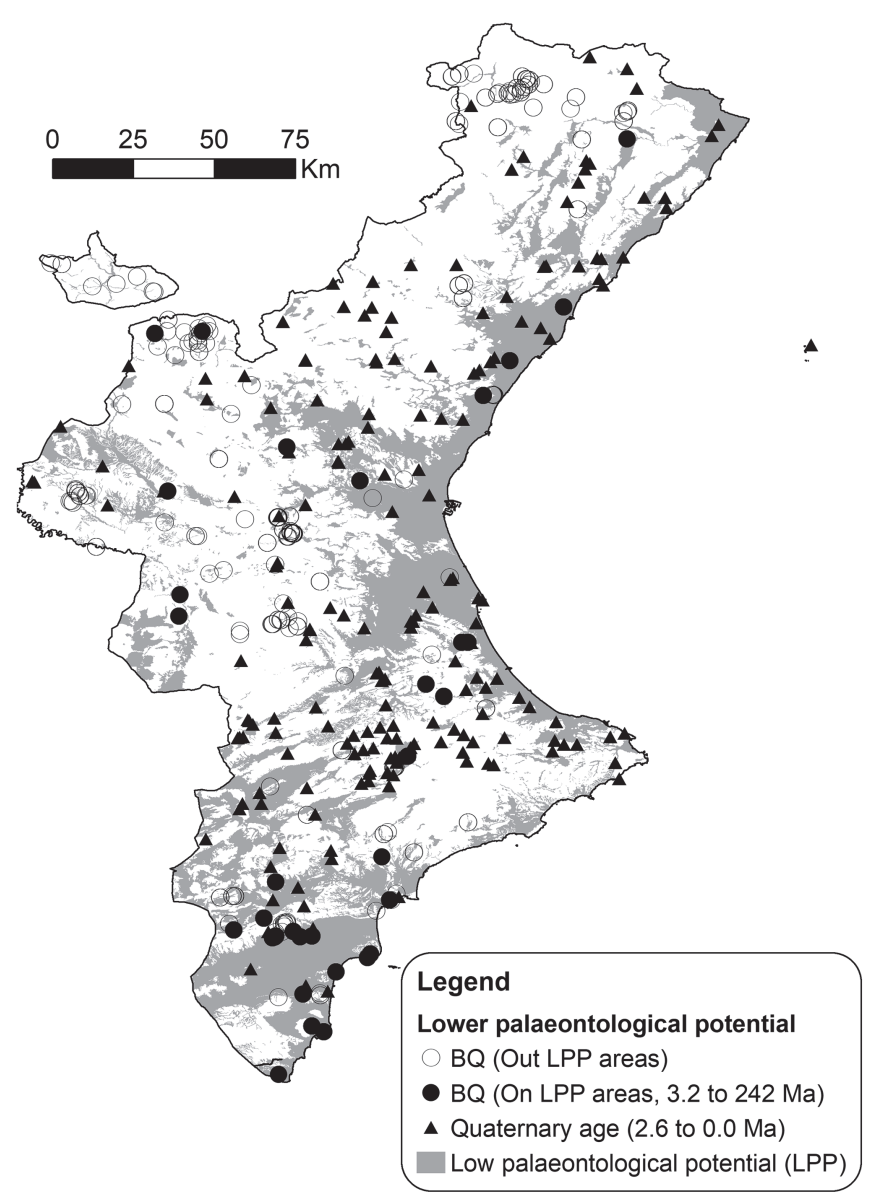

Figure 1. Lower palaeontological potential (LPP) areas in the Valencian Community and palaeontological localities according its age and location. BQ: Before to Quaternary. Source: Valencian Government (LPP cartography) and from authors (fossil localities).

The protection of palaeontological heritage (geological in a broad sense) is inscribed, both at state and regional level, mainly within the regulatory framework relating to historical-artistic and cultural heritage (Vegas et al., 2012). However, the protection of cultural heritage is exclusive competence of each autonomous community, having been developed in this sense a complex set of legislative procedures, reaching an anomalous state in the case of the Valencian Community. The particular competence distribution between State and Autonomous communities that our legal order promotes (Aparicio, 1981) allows comparative torts as the previously commented among territories belonging to the same country.

As pointed out in the Law 4/1998 (art. 11, section 6 ), there are projects outside environmental impact assessment, but containing in its actuation area elements from the General Valencian Cultural Heritage Inventory or even, only of archaeological or palaeontological nature, that therefore undergo to the MIP procedure, according to Decree 208/2010.
The described situation leaves the protection of the palaeontological heritage in clear disadvantage in front of the archaeological heritage in the daily administrative management in the Valencian Community. This reality leads us to denounce the existing situation and to propose simple legislative changes in Decree 208/2010 that would reverse this situation and drive us to the establishment of a similar evaluation framework for both sets of assets.

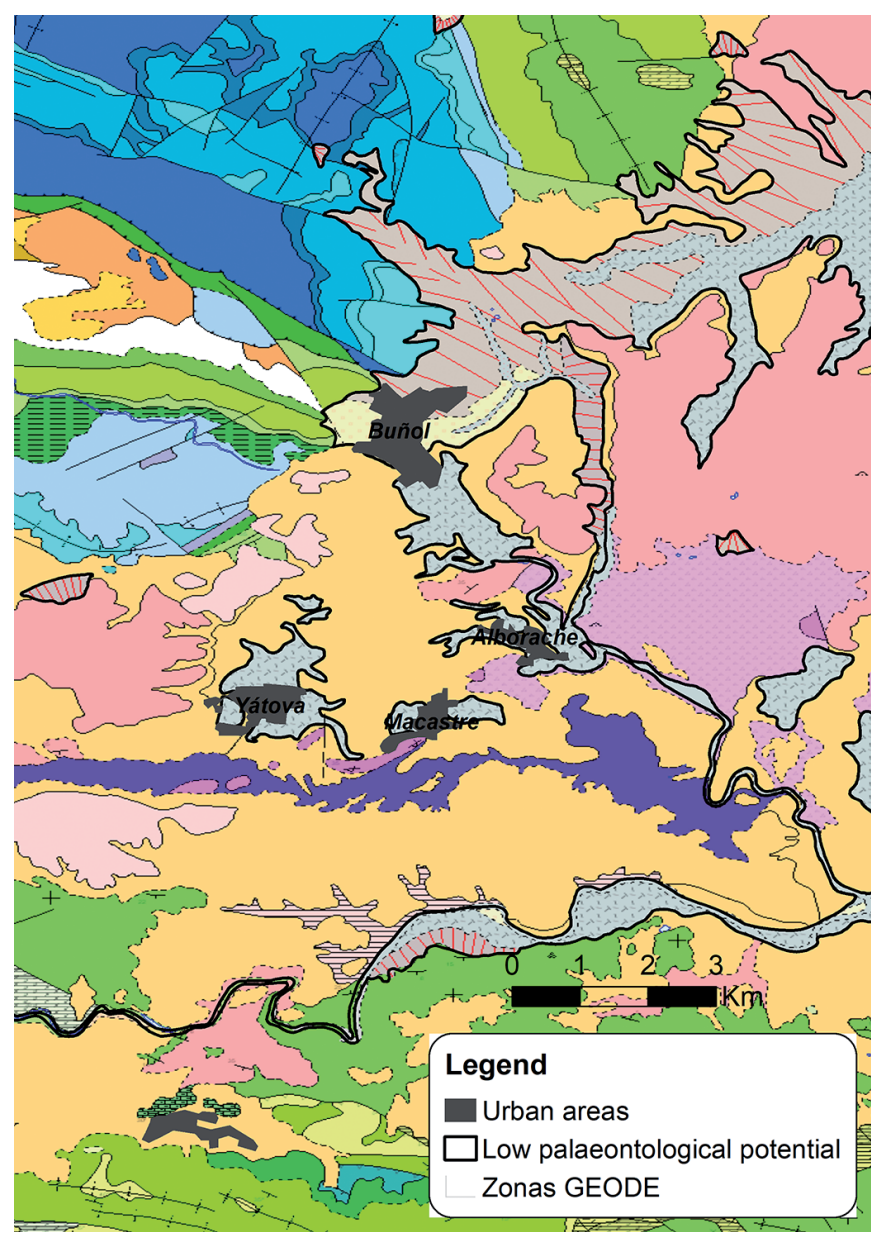

Figure 2. Sample of low palaeontological potential cartography in the Valencian Community. Quaternary age areas are comprised between black lines. 721 geological map. GEODE: Cartografía digital continua a escala 1:50000. Instituto Geológico y Minero de España (IGME).

\section{ARCHAEOLOGICAL AND PALAEONTOLOGICAL HERITAGE MANAGEMENT IN QUATERNARY CONTEXTS}

Article 40 of Title V (Archaeological Heritage) of the Spanish Law on Historical Heritage (Law 16/1985, of June 25) states that "Geological and palaeontological elements related to the history of man and his origins and antecedents 
are part of this Heritage (Archaeological) (author's note)." This contradicts what Law 42/2007 of the Spanish State establishes that, it is the type of element that defines the type of heritage. Article 41 of Law 16/1985 states that "For the purposes of this Law, archaeological excavations are carried out on the surface, in the subsoil or in underwater environments in order to discover and investigate all kinds of historical or palaeontological remains, as well as the related geological components". This is aggravated in practice by the null formation in geology and palaeontology of archaeology graduates that prevents them from recognizing which elements of the geology from a deposit are relevant, and therefore can be an essential component of the geological heritage. The previous fact contradicts the vision of palaeontology and heritage derived by the Spanish legislation on Natural Heritage since 1989 (Law 4/89, on the conservation of natural spaces and wildlife) (Alcalá \& Morales, 1994; Morales, 1996), and especially since 2007 with the promulgation of Law 42/2007 on Natural Heritage and Biodiversity (Morales, 1996; Meléndez \& Soria, 1999). Despite more than ten years have passed from the publication of Law 42/2007 on Natural Heritage and Biodiversity, this conflict of competences has not been resolved yet (RuizSánchez, 2005; Marquina-Blaso \& Ruiz-Sánchez, 2018). At this moment, not only two sectorial legislation sets have competences in the matter, extending these to other administrative fields as those of activities authorization (not directly linked to the environmental impact assessment). Until a modification of the Law of Historical Heritage addresses this issue and ends up applying what the current scientific knowledge clearly points out, which is the character as Natural Heritage of the Palaeontological Heritage, this situation will repeat in the time.

\section{GEOLOGICAL MAPPING, PALAEONTOLOGICAL POTENTIAL AND PRECAUTIONARY PRINCIPLE}

In most cases, geological mapping at scale 1:50000 developed by IGME in recent decades, constitutes an excellent initial framework to know the geological reality of a territory as large and geographically diverse as Spain. To consider this cartography as definitive, and even more, to relate the palaeontological potential from a territory only to the age of the mapped materials does not appear to be the best proposal the administration can offer for the evaluation of this heritage.

This particular situation in the Valencian Community is really surprising if it is related to the use procedures in the framework of risk management corresponding to the decision making phase (Communication EU-[COM(2000) 1 final] on recourse to the precautionary principle). The precautionary principle should be applied as long as there is no absolute certainty that the information on which it is based is complete and sufficient to precede to a decision (Ruiz-Sánchez, 2018). Any professional in geology or palaeontology knows the difficulty of acquiring knowledge, even if it is only representative of a small area of work. Any of these areas of work presents a geological context sufficiently complex and diverse in which they meet normally not one, but a set of processes that have been chained up and end up shaping a complex reality (Santisteban, 2013). According to the General Valencian Cultural Heritage Inventory, with respect to the archaeological interest the palaeontological sites in the Valencian Community consist in: 12 out of $1843(0.65 \%)$ in the BIC (Element of Cultural Interest) category and 4 out of $5186(0.08 \%)$ as Elements of Local Relevance (BRL). Available online, each element classified as BIC or BRL includes information on its location and administrative features. Again, a clear difference between the archaeological and palaeontological information available for consultation and management is shown.

How can we pretend to extend that knowledge (on a larger scale, more exhaustive) to areas much more extensive and with a complexity of domains, geological contexts like those represented in a territory like Valencian Community? Currently, neither in the most intensively worked places in Spain from the geological and/or palaeontological point of view, it can be considered that we have that degree of knowledge that the Valencian administration seems to presume when placing to evaluate the palaeontological potential using maps 1:200000, or at best the 1:50000 series. A procedural error lies in the representativeness that causes the simplification of scales in the cartography used. For example, dinosaur footprints of the BIC of Corcolilla (Alpuente, Valencia) of $200 \mathrm{~m}^{2}$ covers an extension of 0.2 $\mathrm{mm} \times 0.4 \mathrm{~mm}$ in the cartography of scale 1:50000 and these maps are the ones that are used for the synthesis to scale 1:200000.

With regard to Quaternary (Pleistocene and Holocene), there is a serious deficit of cartographic knowledge in the 1:50000 geological maps from IGME. In addition, the materials from these series are found in alluvial areas, where many villages of the Valencian Community with great urban and industrial pressure are settled, involving destruction or sealing.

Ruiz-Sánchez (2018) indicates "restricting the palaeontological potential from a region to areas older than Quaternary, rather seems a political decision related to reserving to Archaeology the study of these contexts and leaving those of preceding ages for palaeontology". In our opinion, the nature of the object and not its age should be emphasized over any other consideration.

From various sources consulted, it has been possible to develop a database of palaeontological deposits in the Valencian Community from ages between the Triassic and the Holocene. Two major categories of deposits according 
to age can be established: on the one hand, those older than Quaternary (396), and on the other hand, those aged between 2.6 and $0.0 \mathrm{Ma}$ (202) (Fig. 1). Regarding the areas of low palaeontological potential provided by the website of the Education, Research, Culture and Sports Department of the Valencian Government, 145 localities of Quaternary age are located outside these areas, normally corresponding to karst fillings on rocks of the Mesozoic, while 94 other localities of an age prior to Quaternary would be located on these areas. That is, about $24 \%$ of locations prior to Quaternary would be outside their actual biostratigraphic context and another $71.8 \%$ of those of Quaternary age could be confused if they are only related to the age of the mapped materials where they are located (Fig. 1; Table 1).

Table 1. Number of localities shown in Fig. 1 according its location in respect to the lower palaeontological potential (LPP) areas.

\begin{tabular}{lc}
\hline \multicolumn{1}{c}{ Age categories and related LPP } & Number of localities \\
\hline Before to Quaternary and on LPP & 94 \\
Before to Quaternary and out of LPP & 302 \\
Quaternary and on LPP & 57 \\
Quaternary and out of LPP & 145 \\
\hline
\end{tabular}

\section{M O D I F I C A T I O N S O F T H E PROCEDURES OF ASSESSMENT OF THE PATRIMONIAL IMPACT ON PALAEONTOLOGY IN THE TERRITORY OF THE VALENCIAN COMMUNITY}

In accordance with the provisions of Annex II to Decree 208/2010, and as regards the technical part of the heritage impact assessment procedure on the goods belonging to the Valencian cultural heritage, this must include: 1) description of the physical environment (medium, soil, vegetation, orography) and historical and archaeological background; 2) description of the project; 3) cultural value of the established heritage elements (historical, artistic, architectural, ethnological and archaeological); 4) proposal for protective measures on verified goods; 5) standardised records of archaeological sites, incorporating cadastral cartography of location and proposed area of protection; 6) route of GPS (itinerary of prospection); and, 7) graphic documentation (plans to scale from 1:5000 to 1:50000).

If the palaeontological heritage assessment procedure delimits that the planned performance is wholly or partly outside areas of low palaeontological potential, the promoter shall include: 1) description of the project, and 2) maps at different scales (1:5000-1:50000), with plot mapping and area of affliction. Normally, if there are indications of presence of palaeontological heritage, the promoters collect information again from the administrative organ of Culture. In this case, they should be based on data from the deposits that the administration owns and not from the cartography of low palaeontological potential.

In our view, the assessment of palaeontological heritage is not really a procedure based on the application of the precautionary principle (Communication EU-[COM(2000) 1 final] on the use of the precautionary principle). The information gathered from a partial consultation of the bibliography has allowed us to establish the presence of about 600 palaeontological localities in the Valencian territory, a number considerably higher than the number of palaeontological sites listed by the administration, which must be around half of this quantity. We can deduce that the actual number of palaeontological sites known in the Valencian Community is even much greater than the 600 localities that we include in our cartography, which allows us to conclude that absence of a suitable palaeontological cartography (inventories) invalidate the procedure hitherto used by the Valencian administration, based on the chronostratigraphic cartography query, and therefore must be radically modified.

Our proposal passes inexorably by a radical change in the procedure of assessment of the environmental impact on the palaeontological heritage linked to plans, programs and projects within the framework of Decree 208/2010 of the Valencian Government. As currently it happens in archaeology, it would be necessary to incorporate some kind of in situ evaluation of the possible incidence to any palaeontological site. We believe that this procedure should be based on an appropriate characterization of the geological context where the evaluated action is located and on the other hand, an evaluation of the palaeontological content through a direct intervention (prospecting) or the result of the relationship between facies represented in the area of action and actual palaeontological potential of those same facies in the nearest geological environment (known deposits). We propose that the evaluation procedure linked to palaeontology must be based in developing information about: 1) administrative and planning context of the planned action (cadastral framework and zoning with indication of the use to which this area of the municipality is reserved);2) general geological context (folding system, tectonostratigraphic domain, Cenozoic sedimentary basin, tectonic scope, etc.); 3) stratigraphic column of reference with indication of the level where the action is located, accompanied by schematic maps of geological, lithological character of facies or of sedimentary environments on an appropriate scale to the proposed intervention (1:100-1:1000). These latter maps should never come from the direct transformation, on a smaller scale, of the data of the MAGNA cartography of IGME; 4) evaluation of the palaeontological content of the area of action by direct intervention (prospecting and/ or excavation), or where appropriate by relation of the 
facies represented in the area of action and palaeontological potential of these same facies in the nearest geological context (geological basin, tectonostratigraphic domain where the action is located); and, 5) proposal of corrective and/or compensatory measures in case of direct affection of the performance to the palaeontological heritage. In the case of a compatible condition, proposals should be included, such as the elaboration of fossil reference collections of the area and/or the identification and valuation of the palaeontological heritage detected that allow, as far as possible, to reconcile the planned actions and the maintenance of these patrimonial values. From our point of view, biologists, geologist and environmental licentiate or graduated with formation in applied palaeontology must be competent technicians to elaborate these reports, as well as the technicians in charge evaluating these procedures in the administration.

\section{CONCLUSIONS}

The unequal application of the impact assessment procedures to the archaeological and palaeontological heritage in the Valencian Community leads to a situation of comparative tort. The palaeontological heritage impact assessment is based in an incomplete and confusing cartography consultation procedure. Low palaeontological potential cartography (LPP) has been erected as an instrument to reject a considerable amount of projects possibly affecting to palaeontological heritage. Projects in which its work area is entirely integrated into these LPP zones are excluded from the specific impact assessment procedures on cultural heritage, and therefore this situation must be denounced.

To homogenise actuations on archaeologic and palaeontologic heritage linked to the impact assessment included in cultural laws, legislative changes in the 208/2010 Decree of the Valencian Government are necessary. Based in a fieldwork methodology, a report including specific information about: 1) administrative and planning context of the planned action; 2) general geological context; 3) stratigraphic column with indication of the affected levels by the project; 4) palaeontological potential from the projected area; and, finally, 5) proposal of corrective and/or compensatory measures, must be erected to evaluate impact on palaeontological heritage of a project.

\section{REFERENCES}

ABPP_GVA (Conselleria d'Educació, Investigació, Cultura i Esports). http://www.ceice.gva.es/es/web/patrimoniocultural-y-museos/procedimiento-relacionado-conlos-estudios-de-impacto-ambiental-paleontologia-. [Consulta:17/03/2019].
Agència del Medi Ambient. 1987. Mapa Geocientífico de la Provincia de Alicante a Escala 1:200.000. Conselleria d'Administracions Públiques (Generalitat Valenciana), Alicante.

Alcalá, L. \& Morales, J. 1994. Towards a definition of the Spanish Palaeontological Heritage. In: Geological and Landscape Conservation (eds. O'Halloran et al.). Geological Society of London, 57-61.

Aparicio, M.A. 1981. Introducción al Sistema Político y Constitucional Español. Editorial Ariel, Barcelona.

COMUNICACIÓN EU-[COM(2000) 1 final] on the application of the precautionary principle [en línea] $<$ https://eur-lex.europa. eu/legal-content/ES/TXT/?uri=LEGISSUM\%3A132042> [Consulta:15/04/2018].

Gutiérrez, G., Elizaga, E., Goy, J.L., Nieto, M. \& Robles, F. 1984. Mapa Geológico de la Provincia de Valencia. Diputación Provincial de Valencia, Valencia.

LEY 16/1985, de 25 de junio, del Patrimonio Histórico Español. Boletín Oficial del Estado, no 155 , de 29 de junio de 1985.

LEY 4/1989, de 27 de marzo, de conservación de los espacios naturales y de la flora y fauna silvestres. Boletín Oficial del Estado, no 74 , de 28 de marzo de 1989.

LEY 42/2007, de 13 de diciembre, del Patrimonio Natural y de la Biodiversidad. Boletín Oficial del Estado, n. ${ }^{\circ} 299$, de 14 de diciembre de 2007.

Marquina-Blaso, R. \& Ruiz-Sánchez, F.J. 2018. El dilema del patrimonio paleontológico: ¿es posible su protección a través de las leyes de conservación de espacios naturales? PH: Boletín del Instituto Andaluz del Patrimonio Histórico, 94, 324-325.

Meléndez, G. \& Soria, M. 1999. Situación actual del patrimonio paleontológico en España. PH: Boletín del Instituto Andaluz del Patrimonio Histórico, 29, 128-141.

Morales, J. 1996. El Patrimonio Paleontológico. Bases para su definición, estado actual y perspectivas futuras. In: El Patrimonio Geológico. Bases para su Valoración, Protección y Utilización. Serie Monografías. MOPTMA, Madrid, 39-51.

Robles, F., López, J.L., Goy, J.L. \& Zazo, C. 1991. Mapa Geológico de la Provincia de Castellón 1:200.000. Generalitat Valenciana, Valencia.

Ruiz-Sánchez, F.J. 2005. La legislación de medio ambiente y la protección del patrimonio paleontológico en la Comunidad Valenciana (España). Revista Española de Paleontología, No Extraordinario, 119-124.

Ruiz-Sánchez, F.J. 2018. Principio de precaución y agravios comparativos en la gestión de la arqueología y la paleontología por parte de las administraciones: el caso de la Comunidad Valenciana. PH: Boletín del Instituto Andaluz del Patrimonio Histórico, 94, 301-303.

Santisteban, de C. 2013. Cadenas de clases en la diversidad geológica. In: Actas de la X Reunión Nacional de la Comisión de Patrimonio Geológico. Sociedad Geológica de España, Segovia: 485-493.

Vegas, J., Alberruche, E., Carcavilla, L., Díaz-Martínez, E., García-Cortés, A., García de Domingo, A. \& Ponce de León, D. 2012. Guía Metodológica para la Integración del Patrimonio Geológico en la Evaluación de Impacto Ambiental. IGME y MAGRAMA, Madrid. 